\title{
Mereological Composition in Analytic and Buddhist Perspective ${ }^{1}$
}

Abstract: Comparing Buddhist and contemporary analytic views about mereological composition reveals significant dissimilarities about the purposes that constrain successful answers to mereological questions, the kinds of considerations taken to be probative in justifying those answers, and the value of mereological inquiry. I develop these dissimilarities by examining three questions relevant to those who deny the existence of composite wholes. The first is a question of justification: What justifies denying the existence of composite wholes as more reasonable than affirming their existence? The second is a question of ontology: Under what conditions are many partless individuals arranged composite-wise? The third is a question of reasonableness: Why, if there are no composites available to experience, do "the folk" find it reasonable to believe there are? I motivate each question, sketch some analytic answers for each, develop in more detail answers from the Theravādin Buddhist scholar Buddhaghosa, and extract comparative lessons.

Keywords: Buddhaghosa, cooperative behavior, nihilism, soteriology, Theravāda Buddhism

\section{Introduction}

Compositional holism is the view that some composite exists. Composites, on this view, are wholes with distinct individuals as parts. Even when the parts of a composite are many in number, compositional holism entails that the parts compose an individual that is one is number, namely, a composite whole containing the many as parts. By contrast, compositional nihilism is the view that no composites exist. On this view, many individuals never compose some one

\footnotetext{
${ }^{1}$ I thank the journal's referees for their helpful comments. When possible, I cite to English translations of ancient Buddhist texts. In doing so, I include, for specialists, the standard book, chapter, or other identifying information in addition to the page numbers of these modern editions.
} 
individual, and there are neither wholes nor proper parts thereof. When many individuals seem to compose some whole, there are, according to compositional nihilism, only partless individuals arranged composite-wise.

The merits and relative plausibility of compositional holism and compositional nihilism are active topics of debate among analytic metaphysicians. Paradigmatic putative composites in these debates include sociotechnical artifacts, such as ships and houses, and living organisms, such as persons. Similar paradigm cases appear in Buddhist metaphysics - chariots rather than ships, buildings made of plants (reeds or trees) rather than soil (bricks), and persons, too, albeit conceptualized as sentient beings rather than living organisms. Similar debate appears, as well. Indian Buddhists tend toward the view that there are no chariots, no houses, no persons. Their Brahmanical peers tend to disagree.

Debates between Buddhists and Brahmans tend to focus on whether composites are real rather than on whether composition occurs. Buddhists variously characterize composites as unreal, conventions, illusions, conceptual constructions, or appearance-only. Some mention relations akin to mereological composition, such as associative union, collective conjunction, and mutually conditioning causation. (These relations appear, respectively, in Nāgārjuna, Mūlamadhyama-kakārikā [2003: 14.1, p. 141]; Asañga, Abhidharma Samuccaya [2001: 1.3, pp. 74-76]; and Jizang [吉藏], Commentary on the Middle Way [Zhongguan lun shu 中觀論疏]

[n.d.: T42.1824.132a]). There is no straightforward mapping between analytic mereology and Buddhist mereology. There are, nonetheless, suggestive parallels.

Analytic inquiry regarding compositional nihilism addresses three key questions. First, presuming that the contrast between views is not merely verbal, what justifies compositional 
nihilism as more reasonable than compositional holism? Second, under what conditions are many partless individuals arranged composite-wise? (Tallant 2014 calls this the special arrangement question.) Third, why, if there are no composites available to experience, do 'the folk' find it reasonable to believe in the existence of ships, houses, and persons - presuming, of course, that they have some reason for their confidence? (Korman 2009 calls this the problem of reasonableness.) Buddhist inquiry addresses these questions as well, albeit under different formulations. For example, rather than explain why 'the folk' find it reasonable to believe in composites, Buddhists explain why sentient beings are prone to assuming that composites are real. Similarly, rather than propose conditions under which many are arranged composite-wise, Buddhists propose conditions under which composites are realities of convention but not realities of the ultimate.

Buddhist metaphysics invokes paradigms of putative composition akin to those of analytic metaphysics, and Buddhists address questions about composites (or the lack thereof) akin to those from analytic inquiry. In this article, therefore, I compare Buddhist approaches to mereological composition to analytic approaches. In doing so, I interpret Buddhists who deny the (nonconventional) reality of composites as proponents of compositional nihilism. For example, when the eminent nun Vajirā proclaims, in Discourse with Vajirā/Vajirā Sutta (Bodhi 2000: Samyutta Nikāya 5.10, p. 230), that she is a heap of sheer construction rather than a person, I interpret her as maintaining that, whatever the many individuals are that her heap happens to be, they do not compose a person.

Because the Buddhist tradition is vast and diverse, delving into the details of compositional nihilism in the Buddhist tradition requires narrowing the scope of inquiry. My discussion focuses, accordingly, on the views of the monk Buddhaghosa. Buddhaghosa is 
massively influential in the Theravādin tradition of Indian Buddhism. His work has received recent attention within analytic philosophy of mind (Ganeri 2017). There also has been some attention to his views about ethics and agency (Heim 2013). Attending to his metaphysics thereby facilitates a more complete view of his philosophical contributions.

Buddhaghosa's main work is Path of Purification/Visuddhimagga, composed in the Pāli language during the early fifth century CE. Path of Purification has been an authoritative commentary for the Sinhalese lineage of the Theravādin tradition. It makes frequent reference to earlier Buddhist discourses from the Pāli Canon. In explicating Buddhaghosa's views about mereology, I refer on occasion to some of these earlier works. For the most part, I also ignore views about mereology from the various Mahāyāna Buddhist traditions. The most salient difference between Buddhaghosa's work and these other traditions is that Buddhaghosa posits, and the others reject, the existence of partless individuals with intrinsic natures. Because Buddhaghosa's approach to mereological composition depends upon this posit, his specific views do not generalize for other Buddhist traditions.

Comparing Buddhaghosa's views about mereological composition with analytic ones risks distorting the content and purpose of Buddhaghosa's metaphysics. This risk is worrisome insofar as the comparison sustains ethnocentric, anti-intellectual, insular philosophical tendencies (see Van Norden 2017). I argue, however, that the comparison reveals significant dissimilarities about the constraints for successful answers to mereological questions and the kinds of considerations that are probative in justifying those answers. I also argue that Buddhaghosa's views about mereological composition point toward interesting issues that remain underexplored within analytic metaphysics. 
In what follows, I proceed by considering, in turn, the questions regarding justification, arrangement, and reasonableness. For each question, I briefly motivate the question and explore its meaning, sketch some typical analytic answers, develop in more detail Buddhaghosa's approach to answering the same question, and extract a comparative lesson. I conclude by considering what value the comparisons might add to analytic investigations of matters mereological.

\section{The Question of Justification}

The first question relevant to comparing Buddhaghosa's views about mereological composition with analytic ones is this: What justifies compositional nihilism as more reasonable than compositional holism? This is a question about whether, on balance, the arguments for compositional nihilism and against compositional holism are more or less plausible than the arguments for compositional holism and against compositional nihilism.

To understand the motivation and meaning for this question, consider the science of cancer. The causes of cancer remain poorly understood. Leading theories of carcinogenesis divide into two broad classes. Most cancer researchers endorse some sort of somatic mutation theory, whereby accumulated DNA mutations on a single somatic cell cause the cell to proliferate uncontrollably. Others endorse the tissue organization field theory, whereby disruption of cellular interactions within tissues causes uncontrollable cellular proliferation (Sonnenschein and Soto 2008). Although somatic mutation theory is the consensus view, tissue organization field theory seems to explain some features of cancer that, from the perspective of 
somatic mutation theory, remain anomalous. So it makes sense to wonder what, if anything, justifies somatic mutation theory as more reasonable than tissue organization field theory.

The question of what justifies compositional nihilism as more reasonable than compositional holism is akin to the question of what justifies somatic mutation theory as more reasonable than tissue organization field theory. I am interested in approaches aiming to identify arguments that, on balance, favor compositional nihilism over compositional holism. I label those who endorse this aim partial toward compositional nihilism.

\subsection{Analytic Approaches to the Question of Justification}

Analytic metaphysicians who are partial toward compositional nihilism invoke three kinds of argument. The most challenging tend to be conceptual. Conceptual arguments invoke only a priori evidence available through careful reflection upon mereological concepts. Theodore Sider's (1993) argument from the possibility of gunk is a paradigmatic example. Other arguments for compositional nihilism are empirical. Empirical arguments invoke a posteriori evidence available through careful observation. Adam Caulton's (2016) argument from the permutation invariance of fermions in quantum physics is a paradigmatic example.

Gideon Rosen and Cian Dorr, among others, maintain that conceptual and empirical arguments are poorly suited to resolving debates about mereological composition (2002: 155). Conceptual arguments are bound to fail, they argue, because neither compositional nihilism nor compositional holism is analytically inconsistent. Each is compatible with some reasonable definition of parthood. Nor is there any a priori impossibility in supposing that some individuals compose a whole, or that isolation among individuals is sufficiently extensive to preclude 
composition. They argue, further, that observational and experimental evidence is irremediably theory-laden, rendering the views empirically untestable.

There is a third kind of argument for compositional nihilism. Ideological arguments compare competing metaphysical views with respect to their ideology. The ideology of a view includes its undefined predicates and logical apparatus. Sider offers a paradigmatic ideological argument. The argument depends upon the observation that compositional holism, but not compositional nihilism, requires an undefined predicate for parthood, and the claim that, ceteris paribus, a view that enjoys more ideological parsimony than its competitors is more likely true (Sider 2013: 238-39).

\subsection{Buddhaghosa's Approach to the Question of Justification}

Buddhaghosa tends to prefer conceptual arguments for compositional nihilism over empirical ones. He refers to a paradigmatic conceptual argument that appears in a Pāli text known as Questions of King Milinda/Milinda Pañha (Rhys Davids 1890: 2.1, pp. 40-45). The argument is reductionist in nature: there are no wholes, because no putative whole is identical to any one of its proper parts, any collection thereof, or something separate from those parts (see Siderits 2007: 50-56). Consider, for example, a chariot composed of wheels, axles, frame, and so on. The chariot is not identical to the wheels, the axles, or the frame. It is not identical to the collection of wheels, axles, and frame. Nor is it identical to something other than these parts. Hence, the argument concludes, although we designate the collection of parts as a chariot, there is no chariot (Buddhaghosa 2010: 18.28, p. 617). 
A paradigmatic empirical argument against compositional nihilism derives from the Nyāya tradition of the Brahmans. The argument appears briefly in the Nyāya Sutras of Gotama: There is a whole, because we can hold, pull, and the like (Basu 1913: 2.1.35, p. 33). Consider a heap of chariot wheels, axles, frame, and so on. Suppose the parts are scattered. Rolling the wheels moves only the wheels, rotating the axles moves only the axles, pushing the frame moves only the frame. Then there is no connection and organization among the chariot parts. There is a special relationality present among the parts, the Naiyayikas suppose, when and only when the many compose one whole chariot - a unified composite that, by virtue of its unity, is a unit individual. Heaps, as many rather than one, lack this special relationality, because they lack the unity of unit individuals. Hence, since there is reliable empirical evidence that at least some composites behave as unities, some composites are wholes.

The Naiyayikan argument for compositional holism is an instance of an argument strategy with which Buddhaghosa and other Buddhists are familiar. The strategy involves identifying instances of cooperative behavior wherein many coordinate their actions as one. Compositional Holism follows from the prima facie plausible constraint that coordination requires composition. For example, Questions of King Milinda considers the argument that composite persons exist because persons act. This argument assumes, implicitly, that personal action involves coordination among the person's parts. The same text also considers the argument that composite persons exist because persons are responsible for their action. This argument assumes, also implicitly, that responsibility for an action attaches to an author of the action, and that authorship consists in coordinating the behavior of many into one.

Buddhist responses to the Naiyayikan argument tend to be conceptual rather than empirical, attacking the conceptual constraint on coordination while endorsing the empirical 
evidence about cooperative behavior. I consider this sort of response in a subsequent section. I note here, however, that the response is largely defensive. It aims to undermine the claim that coordination among many requires composition of many into one. It does not demonstrate that coordination among many precludes composition of many into one.

The Buddhist response to the Naiyayika's empirical argument for compositional nihilism illustrates Rosen and Dorr's contention that empirical evidence pertaining to putative cases of composition is theory-laden. Naiyayikan responses to the reductionist argument for compositional nihilism likewise illustrate their contention that conceptual considerations preclude neither compositional nihilism nor compositional holism. Naiyayikas typically reject the contention that wholes are not identical to something other than their constituent parts by conceptualizing wholes as individuals that inhere in their parts, akin to the way Platonic forms participate in their instances. Naiyayikas conceptualize inherence as akin to a glue that joins many together into one but that exists in potency, ready to glue, in the absence of those constituents (Potter 2004: 51). They treat this relation as known by inference rather than observation. Insofar as wholes are identical to special inherence relations that glue their parts together, the reductionist argument for compositional nihilism fails.

The failure of conceptual and empirical arguments to settle debates regarding composition gives rise, among analytic metaphysicians, to ideological arguments about mereological composition. The same failure, in the context of Buddhaghosa's work, does not. The reason, I suspect, is that Buddhaghosa relies upon a fourth kind of argument for compositional nihilism. This kind of argument is absent from analytic metaphysics.

The fourth kind of argument is soteriological. Soteriological arguments invoke considerations that pertain to dangers and vulnerabilities that are existentially charged and 
pervasive in human lives. Buddhist traditions typically identify the fundamental vulnerability as dukkha, discomfort or unease present by virtue of human precariousness in the face of unavoidable change. They typically identify the relevant dangers as beliefs and behavioral tendencies that derive from attachments to unrealistic ideals or desires for particular sorts of objects to persist despite their inevitable demise. Considerations relevant to soteriological arguments include both claims about the capacity of some particular metaphysical view to help ameliorate or remove the relevant dangers and vulnerabilities and a presumption, often implicit, that the efficacy of such views indicates their true.

Buddhaghosa does not marshal soteriological considerations into a soteriological argument. But just before his reference to the reductionist argument from Questions of King Milinda, he gestures toward the materials for such an argument (2010: 18.25, pp. 616-17). The context for his gesture is an effort to explain how to achieve knowledge of oneself as empty of self, as a mere collection of materiality and mentality that is not a composite. He cites an excerpt from Discourse with Vajirā as confirmation. Because the excerpt from this discourse develops advice from Discourse on Sentient Beings/Satta Sutta (Bodhi 2000: Saṃyutta Nikāya 5.10, p. 985), I review this latter discourse (which Buddhaghosa does not cite) before explicating Buddhaghosa's reference to the former. Doing so motivates the premises of a soteriological argument for compositional nihilism.

In Discourse on Sentient Beings, Radha, one of Buddha's trusted attendants, asks about sentient beings. Buddha replies that sentient beings are supports for hindrances and defilements—craving, clinging, and whatever else fosters $d u k k h a$. He gives a sandcastle metaphor, comparing those who act as if there are sentient beings to children who play with sandcastles as if they own them: just as such children cherish and treasure their castles, so too 
those who act as if there are sentient beings cherish and treasure such beings. Then, for those aiming to eliminate $d u k k h a$, he advises against endorsing the existence of sentient beings. He recommends, instead, scattering sentient beings into pieces, rendering them unplayable in the way children, having lost interest in their sandcastles, smash the castles into oblivion.

Buddha's advice in Discourse on Sentient Beings is oriented toward praxis, focusing on how we should act rather than what is the case. It conceptualizes sentient beings as targets for soteriologically dangerous attachments and desires, and it recommends avoiding these dangers by not endorsing the existence of sentient beings. Discourse with Vajirā extracts from this practical recommendation an ontological insight.

In Discourse with Vajirā, Vajirā is meditating beneath a tree. She wonders about the source of her existence as a sentient being and the fate of this sentient being upon her death. Her wondering interferes with her concentration. The discourse depicts the interference as an inquiry from Māra, a malevolent deity. Māra, in this context, is a personification of thinking that fosters clinging attachment; and depicting Vajirā's experience in this way is a literary technique for indicating that Vajirā's wondering promotes dukkha. (For context on why Vajirā's wonderings are problematic, see Discourse with Vacchagotta/Vacchagotta Sutta (Bodhi 2000: Samyutta Nikāya 44.8, pp. 1031-33) and Discourse with Vacchagotta on Fire/Aggi-Vacchagotta Sutta (Ñāṇamoli and Bodhi 1995: Majjhima Nikāya 72, pp. 590-94).)

Vajirā resolves her consternation—-she vanquishes Māra—by doing just what Buddha recommends to Radha. Like a child reducing a sandcastle into unstructured heaps of sand, Vajirā reduces herself to pieces, rendering her existence as a sentient being unplayable: 'Why do you now assume "a sentient being"? Māra, is that your speculative view? This is a heap of sheer construction. Here no sentient being is found. Just as, with an assemblage of parts, the word 
"chariot" is used, so, when the aggregates are present, there is the convention "a sentient being". (my translation.)

Vajirā likens a sentient being to a chariot and the sentient being's constituents-its aggregates - to the chariot's parts. Vajirā contrasts the sentient being with a heap of its aggregates, and the chariot with an assemblage of its parts. She conceptualizes heaps and assemblages as constructions built from aggregates and parts, respectively. She declares that, by convention, folk speak of chariots and sentient beings. She declares, as well, that insofar as these sortals designate composite wholes, there are no chariots or sentient beings.

Like Buddha in Discourse on Sentient Beings, Vajirā conceptualizes her view that she is a sentient being as a source of soteriological danger. She thereby follows Buddha's advice of refraining from endorsing this view. But she does more. She declares that the view is incorrect, that there is no sentient being. She also generalizes, inferring that there are no composites of any sort. Her reasoning thereby furnishes the materials for a soteriological argument for compositional nihilism.

1. Composites are targets for soteriologically dangerous attachments and desires.

2. A metaphysical view is soteriologically safe if and only if the view does not endorse the existence of targets for soteriologically dangerous attachments and desires.

3. Soteriological safety tracks truth.

4. Hence, there are no composites.

The first premise of this argument derives from Buddha's attitude toward sentient beings in Discourse on Sentient Beings, and from Vajirā's generalization of this attitude in Discourse with Vajirā. I introduce the second premise as definitional for the sake of expediency. The third 
premise formalizes the principle through which Vajirā resolves her consternation. She categorizes soteriologically unsafe views as incorrect, and the third premise is the contrapositive for this principle of categorization. The first two premises jointly entail that compositional holism is not soteriologically safe. The third entails, further, that compositional holism is incorrect.

\subsection{Lessons from the Question of Justification}

Contemporary philosophical literature beyond the Buddhist tradition is no stranger to soteriological concerns. For example, in his personal notes, Ludwig Wittgenstein remarks, 'If I am to be REALLY saved, - what I need is certainty —not wisdom, dreams or speculation —and this certainty is faith. And faith is faith in what is needed by my heart, my soul, not my speculative intelligence. For it is my soul with its passions, as it were with its flesh and blood, that has to be saved, not my abstract mind' (1984: 33e).

Yet, for the most part, analytic metaphysics eschews soteriology. Scott Soames offers a plausible explanation for this disregard, claiming that the analytic tradition aims to discern truths rather than useful recipes for living one's life (2003: xiv). Insofar as soteriological considerations address how to live well, it is perhaps unsurprising that some analytic philosophers treat metaphysics as more akin to pure mathematics than religion (see Baron 2018).

Matthew Kapstein (2013) argues that there is an intimate connection between Buddhist epistemology and soteriology from India and Tibet. The soteriological argument for compositional nihilism demonstrates a further connection between (some) Buddhist metaphysics and soteriology. This connection is not restricted to Buddhism, and it is not restricted to any specific stance about the targets for soteriologically dangerous attachments and desires. Any 
soteriology that frames views about composites as dangerous admits soteriological arguments about mereological composition. For example, a Christian soteriology that treats belief in the existence of a personal self as an essential component of motivation to pursue redemption from sin supports a soteriological argument for compositional holism (insofar as personal selves are composites). So, too, does a soteriology that treats belief in the existence of selves as integral to the project of establishing oneself as a self (see Lippitt 2009; Mārandiuc 2018).

Despite the availability of soteriological arguments beyond the confines of Buddhist metaphysics, such arguments are prima facie problematic. The connection between soteriological safety and truth, central to the soundness of soteriological arguments, is far from obvious. For the sake of reducing the counterintuitive quality of this connection, or least helping to identify the source of its strangeness, I reconstruct an argument for the connection from Buddhaghosa's accounts of truth and soteriological danger.

Buddhaghosa endorses an epistemic account of truth whereby true views are views that, when cognized by those capable of penetrating through illusion and deception, lack certain epistemic defects. He remarks, in Path of Purification, that '[truth] is that which, for those who examine it with the eye of understanding, is not misleading like an illusion, deceptive like a mirage, or undiscoverable like the self of the sectarians' (Buddhaghosa 2010: 16.24, p. 508). (For Buddhaghosa's account of understanding, see 2010: 14.3-5, pp. 431-32.) Following the Buddhist teaching of dependent arising, he also endorses a cognitive account of soteriological danger whereby misleading or deceptive cognitions - cognitions that exhibit ignorance by virtue of succumbing to illusion or delusion — are the source of dukkha-inducing attachments and desires (Buddhaghosa 2010: 17.2, 39, pp. 533, 542). Insofar as views that are neither misleading 
nor deceptive are true, while soteriologically safe views are neither misleading nor deceptive, it follows that soteriological safe views are true.

This argument for the connection between soteriological safety and truth is not decisive. For example, one might reject the cognitive account of soteriological danger, locating the source of dangerous attachments in certain felt needs for security while permitting such needs to obtain in the absence of illusion and deception (see Wonderly 2016). Insofar as Buddhaghosa's account of truth entails that all truths are knowable, one also might infer, from Fitch's paradox, that Buddhaghosa's account of truth is incorrect (see Perrett 1999). That these objections depend upon views that are unsettled in the analytic literature is evidence, at least, that the soteriological argument for Compositional Nihilism merits further attention.

\section{The Question of Arrangement}

The second question relevant to comparing Buddhaghosa's views about mereological composition with analytic ones is this: Under what conditions are many partless individuals arranged composite-wise?

To understand the motivation and meaning for this question, consider Conway's Game of Life. The game occurs on an infinite two-dimensional grid. Setup involves designating each square region, or cell, as ON or OFF. This is akin to populating the space with individuals, each corresponding to an $\mathrm{ON}$-cell. Upon activation, the regions switch between $\mathrm{ON}$ and $\mathrm{OFF}$ in accordance with four dynamical rules:

1. Any ON region with fewer than two ON neighbors switches to OFF.

2. Any $\mathrm{ON}$ region with two or three $\mathrm{ON}$ neighbors remains $\mathrm{ON}$. 
3. Any ON region with more than three $\mathrm{ON}$ neighbors switches to OFF.

4. Any OFF region with exactly three OFF neighbors switches to ON.

Depending upon the setup, sometimes heaps of $\mathrm{ON}$-cells recur at regular intervals along a stable trajectory. Players designate these heaps with sortal terms. I present these graphically in figures 1 and 2. For example, players designate any of the four distinct patterns in figure 1 as a glider.
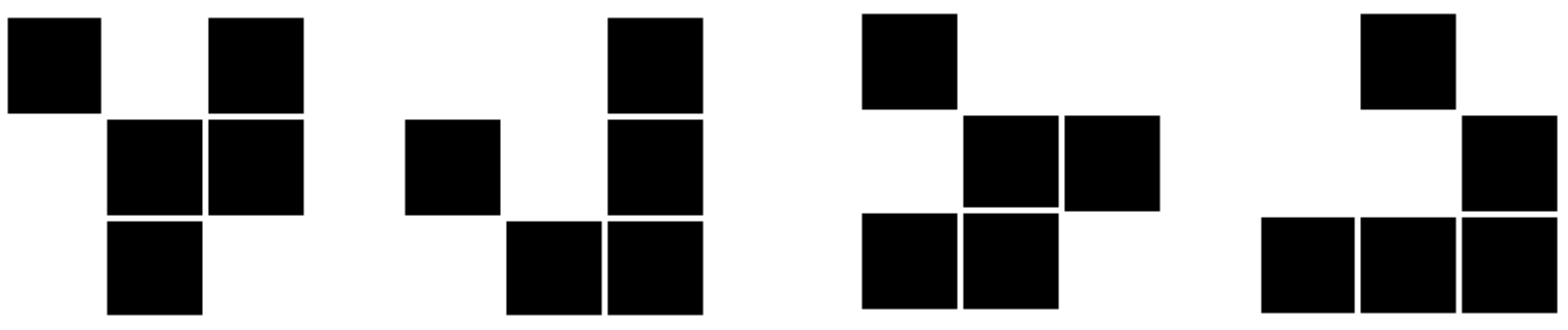

Figure 1-Four glider-like patterns. Each black square represents an ON-cell. Author's graphic design.

ON-cells arranged glider-wise sequentially cycle through four glider-wise arrangements. After four turns, each ON-cell seems to move one region to the southeast (figure 2).
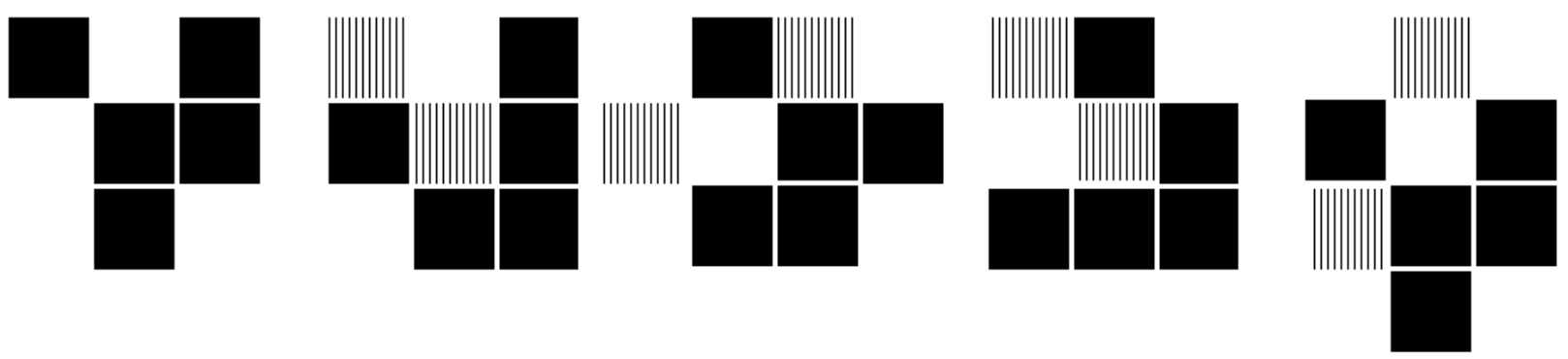
Figure 2-Apparent motion of glider-like patterns. Each striped square represents an OFF-cell that had been an ON-cell during the game's immediately preceding turn. Author's graphic design.

The result is that the ON-cells within each heap seem to exhibit collective motion in a southeasterly direction, and each recurring pattern seems to be a state in the dynamical evolution of a composite individual.

\subsection{Analytic Approaches to the Question of Arrangement}

Analytic inquiries into mereological composition often consider the special composition question: Under what conditions do many individuals compose a composite individual? According to Peter van Inwagen, 'When we ask a question of this sort, we are asking a question about the mutual relations that — at least in typical cases — hold among various objects of the same type ... relations in virtue of which they are bound together into a whole (1990: 21).

In the context of the Game of Life, however, the special compositional question is this: Under what conditions do some ON-cells compose something? Potential answers consistent with compositional holism include the following: whenever there is a grouping of ON-cells, no matter how arbitrary; whenever the ON-cells seem to exhibit collective motion; whenever the ON-cells persist indefinitely without change. Only one answer to the special compositional question is consistent with compositional nihilism: never.

There is a question similar to the special compositional question, about failed compositions, for which compositional nihilism allows multiple answers. This is the special arrangement question: Under what conditions are many individuals arranged composite-wise? 
According to Karen Bennett, 'If the [compositional holist] should tell us when and how some simples compose a thing of kind $F$, the [compositional nihilist] should tell us when and how some simples are arranged $F$-wise' (2009: 66).

The simples of which Bennett speaks are partless individuals. $F$ is a sortal for a composite of some sort. The audience - the 'us' - is metaphysicians, those with an interest in discerning a correct view about mereological composition (Bennett 2009: 38). The special arrangement question is akin to the special compositional question because each holism-consistent answer to the special compositional question qualifies as nihilism-consistent answer to the special arrangement question. Consider, in the context of the Game of Life, a version of compositional holism that admits gliders but denies blocks. To the special compositional question, this version answers, 'ON-cells compose something whenever they exhibit collective motion, and not otherwise'. A parallel version of compositional nihilism admits ON-cells arranged glider-wise but rejects ON-cells arranged block-wise. To the special arrangement question, this version of compositional nihilism answers, 'ON-cells are arranged composite-wise whenever they exhibit collective motion, and not otherwise'.

Many answers to the special arrangement question are possible. Rosen and Dorr (2002) offer an apparitional answer, whereby partless individuals are arranged $F$-wise whenever they appear to be an $F$, whenever they 'look and feel and act just like' an $F$ : 'For some things to be arranged house-wise they must cohere; they must collectively possess a certain mass, a certain shape, and so on. If we put some things arranged house-wise on the corner, they would look and feel and act just like a house, whether or not they constituted a single thing' (157-58).

Holly Kantin offers a fictionalist answer: 'The [partless individuals] are arranged $F$ wise if and only if they are arranged in way $W$ and, according to the fiction that there are composites, 
being arranged in way $W$ suffices for composing an object $f^{\prime}$ (2020: 4325, emphases Kantin's). According to Kantin, fictions about composites are conveniences for navigating a composite-free world. These conveniences derive from naïve folk beliefs about reality's ontological furniture. When the beliefs facilitate world-navigation, they likely track collective dynamics that matter to human purposes rather than compositional realities that float free from such purposes (Kantin 2020: 4326, citing Rose and Schaffer 2017).

Kantin's answer to the special arrangement question resembles some interpretations of Buddhist ontology. For example, Jay Garfield (2006) interprets Madhyamikans as maintaining that composites are collectively constituted fictions. They are collectively constituted because their (fictional) properties coincide with properties the folk assign to them by convention. They are also deceptive, because the folk tend to mistake fiction for reality. Similarly, Andrea Sauchelli proposes that Buddhist traditions treat (composite) persons as fictions because entertaining thoughts about persons facilitates everyday social interactions, encourages ethical conduct, and supports interventions to alleviate existentially charged dangers (2016: 1281-82).

\subsection{Buddhaghosa's Approach to the Question of Arrangement}

Garfield's and Sauchelli's fictionalist interpretations of Buddhist mereology diverge from Buddhaghosa's view, which imposes more ontological constraints on $F$-wise arrangements. These constraints pertain to the ways in which individuals relate to each other, rather than to folk convention or personal concern, when they relate in some $F$-wise arrangement.

Buddhaghosa denies that designating a collection of many individuals as one individual entails that the many compose one individual (Buddhaghosa 2010: 18.28, p. 617). But he does not invoke the notion of a composite-wise arrangement. He invokes, instead, the notion of the 
compact, a picturesque way to refer to what Buddhist tradition elsewhere names constructions (see Buddhaghosa 2010: 669n6). Buddhaghosa's discussion of the compact is terse: 'When the resolution of the compact is effected by resolution into elements, the characteristic of not-self becomes apparent in its true nature' (2010: 21.4, p. 667).

The elements are dharmas, partless individuals. The compact is a collection of dharmas that, despite differences among its constituents, is taken to be one. Resolution (or differentiation) of the compact involves attending to the collection as many distinct dharmas. The Theravādin monk Dhammapala, also known as Ācariya, provides an explanatory commentary (in his Paramatthamañjúsá): 'compactness of object is assumed when, although differences exist in the ways in which [dharmas] that take objects make them their objects, those objects are taken as one. But when they are seen after resolving them by means of knowledge into these elements, they disintegrate like froth subjected to compression by the hand. They are mere [dharmas] occurring due to conditions and void' (Buddhaghosa 2010: 668n3).

Buddhaghosa maintains that resolution of the compact reveals that the collection has the characteristic of not-self, by which he means that the collection is not, in fact, one. Interpreting Buddhaghosa's claim in contemporary parlance indicates that, according to Buddhaghosa, the compact is many individuals arranged composite-wise in the absence of composition.

Even if resolution of the compact reveals that many taken to be one are not one, it does not explain what it is to take many as one. So Buddhaghosa's discussion of the compact does not answer the special arrangement question because it does not specify the conditions under which many individuals are such as to be arranged composite-wise. However, Buddhaghosa has the resources to specify these conditions. He defines a mutuality condition as something that assists another, and is assisted by that other, through 'mutual arousing and consolidating' (2010: 17.78- 
79, p. 553). He explains this notion while discussing the relation between materiality and mentality: 'just as when two sheaves of reeds are propped one against the other, each one gives the other consolidating support, and when one falls the other falls, so too, in the five-constituent becoming mentality-materiality occurs as an interdependent state, each of its components giving the other consolidating support, and when one falls owing to death, the other falls too' (Buddhaghosa 2010: 18.32, p. 618).

When explaining how mutuality conditions enter into composite-wise arrangements, however, Buddhaghosa abandons the sheaves of reeds metaphor in favor of a metaphor about symbiosis. The metaphor involves a blind man sitting on crippled man's shoulders, each cooperating with the other to achieve sighted mobility (Buddhaghosa 2010: 18.35, p. 619). According to Buddhaghosa, just as neither the blind man nor the crippled man can travel by their own power and yet, together, they can travel, the powers of human beings arise when materiality and mentality act as mutuality conditions for each other even though such powers reside in neither their materiality nor their mentality. Moreover, although the symbiont has a power that neither of its constituents has separately, and although a human being has powers that their dharmas lack separately, each is many arranged composite-wise rather than one unified composite.

\subsection{Lessons from the Question of Arrangement}

Analytic metaphysicians partial to compositional nihilism tend to ground their answers to the special arrangement question upon a relation between some many arranged composite-wise and cognizers who encounter those many. For Rosen and Dorr (2002: 158), the relation is perceptual: many are arranged composite-wise whenever the many 'look and feel and act just like' some 
composite. For Kantin, the relation is purposive: many are arranged composite-wise whenever their arrangement facilitates navigating a composite-free world. Buddhaghosa, by contrast, grounds his answer to the special arrangement question on a relation that is not human-relative, maintaining that many are arranged composite-wise whenever they assist each other.

Analytic criticisms of nihilist-friendly answers to the special arrangement question tend to focus on relations that are not human-relative. For example, Crawford Elder maintains that when many microparticles are arranged dog-wise, those microparticles 'participate in causing and rewarding judgements that a dog is present [and are] among a plurality of microparticles that forms a maximal, cohesive, separately movable mass' (Elder 2007: 140). He objects that, if there are no dogs composed of microparticles, there is no basis for speaking of cohesive, separately movable masses of matter. Elder's objection is meant to undermine nihilist-friendly answers to the special arrangement question. Insofar as his intuition about how composition works is representative, Buddhaghosa's approach to answering the special arrangement question will seem to be a non-starter.

Consider, however, on behalf of Buddhaghosa's approach, two strategies for responding to Elder's objection. The first strategy aims to undermine the motivation for Elder's view. The soteriological argument for compositional nihilism treats the impulse to conceptualize collections as composites as a source of dukkha-inducing attachments and desires. In the case of Elder's objection, this impulse manifests as an inference from dog-wise arranged microparticles to a composite dog that somehow grounds the cohesiveness of that arrangement. In the next section, I discuss further details about Buddhaghosa's explanation for why this inference is tempting. Suffice it to note, here, that insofar as soteriological safety tracks truth, Elder's inference projects a unity onto dog-wise arranged microparticles that is not, in fact, present. 
The second strategy for responding to Elder's objection aims to bolster the plausibility of Buddhaghosa's approach to answering the special arrangement question. The ontological orientation of Buddhaghosa's approach coheres with scientific research into collective motion. Consider, from the science of ichthyology, the collective motion of fish. Ichthyologists often distinguish individual fish from schools of fish. A school of fish, roughly, is 'a group of three or more fish in which each member constantly adjusts its speed and direction to match those of the other members of the school' (Partridge 1982: 115). Fish are arranged school-wise, accordingly, whenever individual fish are mutuality conditions for each other, each adjusting its behavior to the behaviors of other fish in the school. This mutuality supports collective motion, wherein many fish glide together 'in unison, more like a single organism than a collection of individuals' (Partridge 1982: 114; see also Ward et al. 2008). Schools, moreover, have powers that individual fish lack, such as the power of affording substantial protection from predators (Partridge 1982: 116).

The collective motion of fish schools is akin to the collective behavior of chariots, wherein changing the behavior of some few individuals within a collection of individuals suffices for changing the behavior of the entire collection. Naiyayikas interpret collective behavior of this sort as evidence that the collection composes an individual whole. Elder posits a similar interpretation. A school of fish is a cohesive, separately movable mass of fish. Yet, claims Elder, 'if real at all, [such a mass] would be composed of' its individual constituents (Elder 2007: 140). But scientists explain such behavior without supposing that a school of fish is one rather than many. The simplest such explanation appeals to the Vicsek model of collective motion (Vicsek et al. 1995). 
The Vicsek model represents individuals as discrete particles. The model associates each particle as moving with the same constant absolute velocity. Each particle interacts only with nearby neighbors, and these interactions induce directional changes of motion whereby each particle assumes the average direction of motion of its nearby neighbors. There are also noise sources that influence how particles change direction. The model predicts that, when particle density is sufficiently large and noise levels are sufficiently low, particles orient themselves to move in a similar direction. This self-alignment suffices for collective motion without any assumption about whether the particles jointly compose a single unit (and without any assumption about whether they aim to achieve some common purpose). Hence, contrary to Elder's objection, and contrary to the Naiyayikas, that many individuals behave as a cohesive, separately movable mass does not entail that the many compose one.

Beyond its coherence with scientific research into collective behavior, Buddhaghosa's approach to answering the special arrangement question has an explanatory depth that is missing from answers grounded upon human-relative relations. Consider gliders from the Game of Life. Even if the appearance and behavior of some cells explains why those cells are arranged gliderwise, it does not identify the causal basis for their collective behavior. Nor does the convenience of glider-like arrangements for, say, generating certain states when playing the Game of Life. Similarly, even if the look, feel, and behavior of some individuals explain why those individuals are arranged composite-wise, and even if the practical value of those arrangements explains why the individuals are arranged composite-wise, these explanations do not identify the causal basis for their look, feel, behavior, and utility. Specifying how the individuals so arranged relate to each other, by contrast, suffices for identifying the causal basis for human-relative characteristics 
of composite-wise arrangements. Buddhaghosa's approach to answering the special arrangement question provides precisely such specifications.

\section{The Question of Reasonableness}

The third question relevant to comparing Buddhaghosa's views about mereological composition with analytic ones is this: Why, if there are no composites available to experience, do "the folk" find it reasonable to believe in the existence of ships, houses, and persons?

To understand the motivation and meaning for this question, consider teenage risk taking. Recklessness involves unreasonable risk-taking. Teenagers are especially prone to taking risks. They are also prone to miscalculating the reasonableness of those risks. These miscalculations are not always themselves unreasonable. When the miscalculation is reasonable but the risk is not, one might suppose that the behavior is unduly risky but not thereby reckless (see Stark 2020). To ask, of some teenager's unduly risky but not reckless behavior, why the teenager believed the risk associated with the behavior to be reasonable even though it was not, is to ask two questions. The first is a question about causation: why did the teenager's calculation of risk diverge from reality? The second is an evaluative question: why, despite this divergence, was the teenager's calculation reasonable?

The question of reasonableness, in the context of compositional nihilism, is akin to the question about undue risk-taking in the absence of recklessness. The question has two components (see Kovacs 2019: 4). It asks why folk beliefs diverge from (putative) mereological reality. It also asks why the folks' beliefs are reasonable despite this divergence. 


\subsection{Analytic Approaches to the Question of Reasonableness}

Analytic metaphysicians who are partial toward compositional nihilism pursue several strategies for answering the question of reasonableness. Some deny the presupposition in the question of reasonableness, maintaining instead that folk beliefs about ships, houses, and persons are true. Van Inwagen's analysis of mereological language is a convenient example. He distinguishes between two contexts of language use, ordinary and philosophical (Van Inwagen 1990: 101-3). Ordinary contexts obtain in 'the ordinary business of life' (Van Inwagen 1990: 102); philosophy contexts obtain in what is often called 'the philosophy room' during conversations about what there is. He claims that, in ordinary contexts, sortal terms designate many arranged compositewise, while in philosophical contexts, when ontology is at issue, each sortal term designates a composite individual. Folk beliefs in the existence of ships, for example, are reasonable, according to Van Inwagen, because they are beliefs about simples arranged ship-wise and, as it turns out, some simples are arranged ship-wise. Compositional nihilism, on his view, amounts to the claim, not that folk beliefs are false, but that philosophical contexts for discussing ships are error-laden, akin to interpreting folk belief in the motion of the sun across the sky as a belief that the sun moves while Earth remains stationary.

Of analytic strategies for answering the question of reasonableness that accept the question's presupposition, two are noteworthy. Trenton Merricks maintains that folk beliefs in composites, although false, are 'nearly as good as true' (2001: 171). A belief that some composite exists is nearly as good as true, according to Merricks, when, although there are no composites, there is some collection of many individuals arranged composite-wise. Merricks proposes that folk beliefs diverge from mereological reality, because the folk are typically unfamiliar with arguments against the existence of composites. He proposes, further, that folk 
beliefs are reasonable despite this divergence, because composite-wise arrangements 'often play a key role in producing, and grounding the justification of' folk beliefs in composites, because folk beliefs do not err for any straightforwardly empirical reason, and because it would be unreasonable in such circumstances to blame those unfamiliar with the relevant arguments for endorsing the existence of composites (Merricks 2001: 172-73).

Whatever its merits, Merricks's strategy for answering the question of reasonableness does not explain why the folk persist after gaining familiarity with arguments for compositional nihilism. David Kovacs's (2019) strategy for answering the question of reasonableness is noteworthy for avoiding this shortcoming. Kovacs proposes an evolutionary explanation for why folk beliefs in composites diverge from reality. According to Kovacs, our distant ancestors were disposed to assign certain qualities to a single object—as with representing greenish, leafy, and trunkish qualities as belonging to one and same tree. These dispositions turned out to be useful for interacting with the environment—or, at least, they turned out not to be maladaptive. Hence, the dispositions survived pressures of evolutionary selection either because their usefulness enhanced chances for survival or because they did nothing to harm those chances. Because dispositions are inheritable, our distant ancestors transmitted the dispositions to us. Because heritable belief dispositions need not track truth, folks believe in composites even though there are none.

Kovacs (2019) pursues a counterfactual strategy for explaining why, despite their divergence from reality, folk beliefs in composites are reasonable. Kovacs considers, first, possible scenarios in which folk beliefs in composites are correct. He proposes, as common ground with those who endorse the existence of composites, that, in these scenarios, folk beliefs in composites would be reasonable. He considers, second, possible scenarios in which folk 
beliefs in composites are incorrect by virtue of the folk being under the spell of a deceptive demon. He argues that, in these scenarios, the demon's exceptional demonic efforts excuse the folk from unreasonableness. He considers, third, putatively actual scenarios in which folk beliefs in composites are incorrect for more mundane reasons. He argues that, in these scenarios, folk beliefs in composites are also reasonable, because the folks' error in these scenarios is just as subtle as their error in demonic scenarios.

\subsection{Buddhaghosa's Approach to the Question of Reasonableness}

Buddhaghosa allows that some beliefs in composites are true in a conventional sense (see 2010:

17.171-72, p. 575). He denies, however, that any such beliefs are true in an ultimate sense (2010:

18.28, p. 617). Buddhaghosa addresses the issue of whether folk belief in the existence of composites is reasonable by explaining why the folk—or, in his parlance, ordinary personsmistakenly believe in the (ultimate, non-conventional) existence of composites. His explanation occurs in an elaborate metaphor.

Just as the butcher, while feeding the cow, bringing it to the shambles, keeping it tied up after bringing it there, slaughtering it, and seeing it slaughtered and dead, does not lose the perception 'cow' so long as he has not carved it up and divided it into parts; but when he has divided it up and is sitting there, he loses the perception 'cow' and the perception 'meat' occurs; he does not think 'I am selling cow' or 'They are carrying cow away', but rather he thinks 'I am selling meat' or 'They are carrying meat away'; so too this [monk], while still a foolish ordinary person ... does not lose the perception 'living being' or 'man' or 'person' so long as he does not, by resolution of the compact into elements, review this body, however placed, however disposed, as consisting of elements. But 
when he does review it as consisting of elements, he loses the perception 'living being' and his mind establishes itself upon elements (Buddhaghosa 2010: 11.30, p. 345).

Buddhaghosa's metaphor is meant to explain how resolution of the compact reveals that persons are not composites. But the metaphor also indicates some reasons why the folk might fail to resolve the compact.

The butcher neglects to carve his cow into parts when mundane affairs demand his attention. Because the butcher works for a living, he must feed his cow, tend to its needs, and arrange for its slaughter. In all these tasks, the butcher attends to the cow as a single individual rather than many cow parts. The butcher's attentional disposition even might enhance the quality of bovine care he is able to offer the cow. Only when these other tasks are complete—only when the butcher 'has divided [the cow] up and is sitting there' - might the butcher turn his attention to resolving the cow into portions of meat.

The folk, likewise, neglect to resolve persons into their parts. Like the butcher, and unlike mendicant monks, the folk must work for a living. They must tend to their family, to economic transactions, and to political concerns. All of these tasks, by virtue of their sociality, involve attending to persons as single individuals rather than many parts. Only when these other tasks are complete — perhaps upon retiring to old age or forsaking ordinary life for the monastery — might one turn their attention to resolving persons into impersonal elements.

Folk beliefs in the existence of composites diverge from reality, according to Buddhaghosa, because the folk do not direct their attention to persons in the right way. The butcher focuses on the demands of raising cattle. The folk focus on the demands of ordinary living. These demands prevent the folk from developing the intellectual and practical skillssuch as skills in analysis and meditation — necessary to discern correctly what there is (and what 
there is not). Lacking these skills, the folk endorse as correct ontologies of convenience, failing to realize that their conventions for navigating ordinary life are mere constructions imposed upon a composite-free reality. (For his analysis of the relation between conventional constructions and ignorance of reality's nature, see Buddhaghosa 2010: 17.62-64, pp. 548-49.)

Just as conspiracy theories might be convenient to believe despite being unreasonable, that believing in composites is convenient does not entail that it is reasonable. Certain features of traditional Buddhist culture, however, indicate that the reasonableness of belief in composites likely follows from the demandingness and allure of ordinary living. Buddhist tradition typically distinguishes the life of a monk from the life of a householder. Monks live in dependence upon the generosity of others, relying upon alms for their sustenance. Freed from demands to contribute to the economy, they focus upon developing their meditative skills, memorizing Buddhist scriptures, questioning and interpreting difficult texts and arguments, and ridding themselves of attachment (see Buddhaghosa 2010: 14.28, p. 438). Householders, by contrast, live in dependence upon their labor, relying upon commerce for their sustenance. They focus on working with diligence to amass wealth, maintain their good name, and conduct themselves responsibly in dealing with others (see Buddhaghosa 2010: 1.23, p. 12).

The life of a householder is demanding. In premodern cultures, very few achieve the sort of success that would free them from labor. Even in modern cultures, a life spent laboring often fosters habits that interfere with a willingness to forego the pursuit of wealth and pleasure in favor of more austere monastic living. For those born to a life of labor, attending to the demands of ordinary life is reasonable. Insofar as our attentional resources are limited in ways that preclude householders from immersing themselves in monastic practices, neglecting the skills necessary for correctly discerning what there is (and what there is not) is also reasonable. 
Because, according to Buddhaghosa, precisely this sort of neglect explains why folk beliefs about composites diverge from reality, it follows that folk beliefs in the existence of ships, buildings, and persons are reasonable.

\subsection{Lessons from the Question of Reasonableness}

Analytic approaches to mereological composition tend to treat folk beliefs as reliable but defeasible. Whence Daniel Korman, speaking on behalf of the analytic tradition, notes that 'virtually everyone agrees that, even after having presented arguments for their positions, proponents of revisionary philosophical theories - that is, those that deviate from the pretheoretical conception - are required to provide some sort of account of the conflict between their theories and the pre-theoretical beliefs of non-philosophers ("the folk")' (2009: 242).

This agreement explains Van Inwagen's concern with preserving folk belief in the face of an apparently revisionary ontology. It explains, as well, Merricks's effort to conceptualize folk beliefs about mereological composition as 'nearly as good as true' (2001: 171-75) and Kovacs's effort to ground those beliefs upon intrinsic biological dispositions.

Buddhaghosa's approach to mereological composition is also revisionary rather than descriptive. Instead of accommodating folk beliefs about mereological composites as true, or close enough to the truth, he rejects them as incorrect. He also does something absent from revisionary mereologies in the analytic tradition. He invests folk beliefs with soteriological significance. In accordance with the soteriological argument for compositional nihilism, these beliefs are barriers to living well, targets for $d u k k h a$-inducing attachments and desires. Although folk beliefs about composites are reasonable, they are not, according to Buddhaghosa, reliable, 
because they arise from avoidable inattention to the constructed (and therefore unreal) nature of putative composites.

Buddhaghosa's approach to mereological composition explains why his view diverges from beliefs of the folk. But his purpose in doing so is pedagogical rather than ameliorative. Understanding the barriers to living well facilitates efforts to identify targets for dukkha-inducing attachments and desires (of the sort that concern the soteriological argument for compositional nihilism). It also facilitates efforts to remove those barriers. For Buddhaghosa, these efforts involve meditation. Of the many meditation practices Buddhaghosa explains in Path of Purification, perhaps the one most relevant for mereological concerns is 'defining the four elements by groups' (2010: 11.88, p. 359; see also Mahāthera and Bombard 2010: 254-55).

The practice of defining the four elements by groups articulates the contemplation of the body meditation from Discourse on the Foundations of Mindfulness/Satipațthana Sutta (Ñāṇamoli and Bodhi 1995: Majjhima Nikāya 10, pp. 145-55). The focus object for the meditation is one's own body. The goal is to encounter one's body as many partless individuals that do not compose a whole. These partless individuals are the elemental materialities of Theravādin ontology, each defined by reference to its causal power. There is earth with the power to stiffen and support, water with the power to cohere and flow, fire with the power to mature and heat, and air with the power to distend and convey (Buddhaghosa 2010: 11.31, 87, 93, pp. $346,358,360)$. The meditation itself has two aspects. The first involves attending to each of the body's many detectable components. Buddhaghosa lists forty-two kinds of component, including skin and bones, phlegm and sweat, stomach contents and dung, breath and flatus (see 2010: 11.48-82, pp. 350-57). The second aspect of the meditation involves conceptualizing each component as a mere group of elemental materialities and one or more basic qualities (color, 
odor, taste, and nutriment) (2010: 11.85-88, pp. 358-59). The intended experience of the meditation is encountering one's body as the components arranged body-wise, and encountering the components as elemental materialities and qualities arranged component-wise-without succumbing to the tendency to suppose that any arrangement composes a whole. The intended effect of the meditation, achievable through repeated skillful practice, is concentrating on the body in ways that help to undermine beliefs in composites (and other fictions, such as selves) while removing dukkha-inducing attachments and desires (Buddhaghosa 2010: 11.117-125, pp. 366-68; see also Mahāthera and Bombard 2010: 256-58).

If Buddhaghosa's approach to answering the question of reasonableness is correct, and if the meditation-based strategies he recommends for achieving correct mereological views are apt, analytic approaches to answering the question of reasonableness seem to be misguided. Insofar as folk beliefs about mereological composition arise from inattention to what there is, Van Inwagen's approach is counterproductive. If his account is correct, the barrier to living well resides in the philosophy room, where the monks undertake their meditation practices, and those concerned to live well should abandon their monastic isolation to immerse themselves in the ordinary business of householder life.

Merricks's (2001) approach to the question of reasonableness also seems to be implausible from Buddhaghosa's perspective. Merricks locates the source of folk error in their lack of familiarity with arguments. The natural remedy for this lack is studying nihilism-friendly arguments. However, if the source of folk error is failure to resolve composites into constituents, and if this failure arises from finite attentional resources and the demands of ordinary living, adopting a Merricks-style remedy is unlikely to remove the folks' error. Moreover, given the attentional demands of philosophical study, folks who pursue a Merricks-style remedy risk 
compounding their error, especially if they study the arguments Merricks offers, which invoke considerations of vagueness, modality, and multiple location without resolving composites into constituents (see Merricks 2001: 32-52). Devoting more attention to studying these arguments depletes the limited attention folks have available for meditating upon putative composites as, say, mere groupings of partless elements. If Buddhaghosa is correct and meditation is the key to correcting the folks' mereological beliefs, gaining familiarity with arguments in the absence of such practice is likely to impede the sort of concentration that undermines $d u k k h a$-inducing attachments and desires.

Kovacs's (2019) approach to answering the question of reasonableness complements Buddhaghosa's. That folks fail to resolve the compact by virtue of attentional distraction is consistent with the folk having a heritable disposition to believe in composites. There is, however, a sense in which Kovacs's answer is misguided. Identifying heritable dispositions provides no guidance about how to overcome them. Buddhaghosa's approach fills this gap: meditate to resolve putative composites into their partless constituents.

\section{Conclusion}

A central task for the history of philosophy is to facilitate thinking differently about familiar philosophical issues (Antognazza 2015). A central task for cross-cultural philosophy is to create distance from familiar philosophical issues for the sake of interrogating common assumptions (Struhl 2010). Comparing Buddhaghosa's views about mereological composition to analytic ones contributes to both of these tasks. The comparison reveals a justification for compositional nihilism that focuses on the soteriological dimensions of mereological inquiry, an unexplored 
model for making sense of composite-wise arrangements, and a novel perspective for ongoing methodological debates about the comparative propriety of descriptive and revisionary metaphysics. Each contribution merits further attention.

Conceptual and empirical arguments for compositional nihilism are inconclusive (Rosen and Door 2002). Whether ideological arguments improve the dialectical situation remains uncertain (see Bennett 2009; Tallant 2014). Soteriological arguments open new horizons for mereological investigation, with connections to ongoing debates about the nature of truth and less familiar debates about relations between metaphysics and well-being. Buddhaghosa's model for understanding composite-wise arrangements has promising connections to an extensive scientific literature on collective behavior. It also shows that accounts of composite-wise arrangement need not relate such arrangements to our perceptions, beliefs, or purposes. Buddhaghosa's explanation for why the folk tend to mistake these arrangements for composites introduces considerations that favor revisionary metaphysics without referring to the activities and products of the (analytic) philosophy room. His recommendation for how to remedy this mistake also points toward unexplored connections between metaphysical theory and meditational practice.

Buddhaghosa's views about soteriology and meditation are, of course, not definitive. There are many alternatives. This gives some reason to suspect that Buddhaghosa's strategies for addressing mereological issues generalize. The novelty of his approach demonstrates that there is fresh territory to explore even for those who do not share Buddhaghosa's religious concerns.

Nicholaos Jones

The University of Alabama in Huntsville nick.jones@uah.edu 


\section{References}

Antognazza, Maria Rosa. (2015) 'The Benefit to Philosophy of the Study of Its History'. British Journal for the History of Philosophy, 23, 161-84.

Asanga. (2001) Abhidharmasamuccaya: The Compendium of the Higher Teaching. Translated by Sara Boin-Webb. Fremont: Asian Humanities Press.

Baron, Sam. (2018) ‘A Formal Apology for Metaphysics'. Ergo, 5, 1030-60.

Basu, B. D., ed. (1913) The Nyāya Sutras of Gotama. Translated by Mahâmahopâdhyâya Satiśa Chandra Vidyâbhușana. Allahabad: Panini Office.

Bennett, Karen. (2009) 'Composition, Colocation, and Metaontology'. In David J. Chalmers, David Manley, and Ryan Wasserman (eds.), Metametaphysics: New Essays on the Foundations of Ontology (New York: Oxford University Press), 38-76.

Bodhi, Bhikkhu, trans. (2000) The Connected Discourses of the Buddha: A New Translation of the Samyutta Nikāya. Vol. 1. Boston: Wisdom Publications.

Buddhaghosa, Bhadantacariya. (2010) The Path of Purification/Visuddhimagga. Translated by Bhikkhu Náóamoli. 4th ed. Kandy: Buddhist Publication Society.

Caulton, Adam. (2016) 'Is Mereology Empirical? Composition for Fermions'. In Tomasz Bigaj and Christian Wüthrich (eds.), Metaphysics in Contemporary Physics (Leiden: Brill), $293-322$.

Elder, Crawford L. (2007) 'On the Phenomenon of "Dog-Wise Arrangement”'. Philosophy and Phenomenological Research, 74, 132-55.

Ganeri, Jonardan. (2017) Attention, Not Self. New York: Oxford University Press. 
Garfield, Jay L. (2006) 'Reductionism and Fictionalism: Comments on Siderits’s Personal Identity and Buddhist Philosophy'. APA Newsletter on Asian and Asian-American Philosophers and Philosophies, 6, 1-7.

Heim, Maria. (2013) The Forerunner of All Things: Buddhaghosa on Mind, Intention, and Agency. New York: Oxford University Press.

Jizang [吉藏]. (n.d.) Commentary on the Middle Way/ Zhongguan lun shu 中觀論疏. Taishō Shinshū Daizokyō [Taishō Buddhist Canon], volume 42, text 1824.

Kantin, Holly. (2020) 'Why Compositional Nihilism Dissolves Puzzles'. Synthese, 197.10, 43194340.

Kapstein, Matthew T. (2013) “"Spiritual Exercises” and Buddhist Epistemologists in India and Tibet'. In Steven M. Emmanuel (ed.), A Companion to Buddhist Philosophy (Malden: Wiley-Blackwell), 270-89.

Korman, Daniel Z. (2009) 'Eliminativism and the Challenge from Folk Belief'. Noûs, 43, 24264.

Kovacs, David Mark. (2019) 'How to be an Uncompromising Revisionary Ontologist'. Synthese. Published ahead of print, https://doi.org/10.1007/s11229-019-02196-8.

Lippitt, John. (2009) 'True Self-Love and True Self-Sacrifice'. International Journal for Philosophy of Religion, 66, 125-138.

Mahāthera, Paravahera Vajirañāna and Allen R. Bomhard. (2010) Buddhist Meditation in Theory and Practice: A General Exposition According to the Pāli Canon of the Theravādin School. Charleston: Charleston Buddhist Fellowship. 
Mārandiuc, Natalie. (2018) The Goodness of Home: Human and Divine Love and the Making of the Self. New York: Oxford University Press.

Merricks, Trenton. (2001) Objects and Persons. New York: Oxford University Press.

Nāgārjuna. (2010) Nāgārjuna’s Middle Way: Mūlamadhyamakakārikā. Translated by Mark Siderits and Shōryū Katsura. Boston: Wisdom Publications.

Ñāṇamoli, Bhikkhu, and Bhikkhu Bodhi, trans. (1995) The Middle Length Discourses of the Buddha: A New Translation of the Majjhima Nikāya. Kandy: Buddhist Publication Society.

Partridge, Brian L. (1982) 'The Structure and Function of Fish Schools'. Scientific American, $246,114-23$.

Perrett, Roy W. (1999) 'Is Whatever Exists Knowable and Nameable?' Philosophy East and West, 49, 401-14.

Potter, Karl H. (2004) Encyclopedia of Indian Philosophies, vol. 2, Indian Metaphysics and Epistemology: The Tradition of Nyāya-Vaiśeșika before Gangesa. Delhi: Motilal Banarsidass Publishers.

Rhys Davids, T. W., trans. (1890) The Questions of King Milinda. Oxford: Clarendon Press. Rose, David, and Jonathan Schaffer. (2017) 'Folk Mereology is Teleological'. Nô̂s, 51, 238-70. Rosen, Gideon, and Cian Dorr. (2002) 'Composition as a Fiction'. In Richard M. Gale (ed.), The Blackwell Guide to Metaphysics (Malden: Blackwell), 151-74.

Sauchelli, Andrea. (2016) 'Buddhist Reductionism, Fictionalism about the Self, and Buddhist Fictionalism'. Philosophy East and West, 66, 1273-291.

Sider, Theodore. (1993) 'Van Inwagen and the Possibility of Gunk'. Analysis, 53, 285-89. 
Sider, Theodore. (2013) 'Against Parthood'. In Karen Bennett and Dean W. Zimmerman (eds.), Oxford Studies in Metaphysics, vol. 8 (New York: Oxford University Press), 237-93.

Siderits, Mark. (2007) Buddhism as Philosophy: An Introduction. Indianapolis: Hackett.

Soames, Scott. (2003) Philosophical Analysis in the Twentieth Century, vol., The Dawn of Analysis. Princeton: Princeton University Press.

Sonnenschein, Carlos, and Ana M. Soto (2008). 'Theories of Carcinogenesis: An Emerging Perspective'. Seminars in Cancer Biology, 18, 372-77.

Stark, Findlay. (2020) 'The Reasonableness in Recklessness'. Criminal Law and Philosophy, 14, 9-29.

Struhl, Karsten J. (2010) ‘No (More) Philosophy without Cross-Cultural Philosophy’. Philosophy Compass, 5, 287-95.

Tallant, Jonathan. (2014) 'Against Mereological Nihilism’. Synthese, 191, 1511-27.

Vicsek, Tamás, András Czirók, Eshel Ben-Jacob, Inon Cohen, and Ofer Shochet. (1995) ‘Novel Type of Phase Transition in a System of Self-Driven Particles'. Physical Review Letters, $75,1226-29$.

Van Inwagen, Peter. (1990) Material Beings. Ithaca: Cornell University Press.

Van Norden, Bryan W. (2017) Taking Back Philosophy: A Multicultural Manifesto. New York: Columbia University Press.

Ward, Ashley J. W., David J. T. Sumpter, Iain D. Couzin, Paul J. B. Hart, and Jens Krause (2008) ‘Quorum Decision-Making Facilitates Information Transfer in Fish Shoals’. Proceedings of the National Academy of Sciences, 105, 6948-53.

Wonderly, Monique Lisa. (2016) 'On Being Attached'. Philosophical Studies, 173, 223-42. 
Wittgenstein, Ludwig. (1984) Culture and Value. Translated by Peter Winch. Chicago: University of Chicago Press. 